\title{
Evaluation of Tax Incentive Policy for Low Carbon Industries in Indonesia
}

\section{Titi Muswati Putranti*}

\author{
Faculty of Social and Political Sciences University of \\ Indonesia, Depok Campus 16424, Indonesia.
}

\section{Received: November 10, 2015/ Accepted: March 03, 2016}

\begin{abstract}
The increase of industrial activities, which still rely on fossil fuels in the near term, can lead to higher emissions contributions than anticipated in producer or consumer markets. The government has a responsibility to make efforts to transform high-carbon industries towards greater resources efficiency and encourage the use of renewable energy sources. In many countries, to encourage investment and activities in low carbon industries, the goverment provides tax incentives. This study examines a carbon tax and cap-and trade scheme as policy alternatives in Indonesia. Tax incentive schemes in Indonesia at present are not comprehensive, scattered, and have not focused on efforts to reduce green house gases (GHG) emissions in the industrial sectors. Tax incentive policies have not been effective in promoting low carbon industry.
\end{abstract}

Keywords: policy evaluation; tax policy; tax incentives; low carbon industry.

Abbreviations:

\begin{tabular}{lll|}
\hline $\mathrm{CO} 2$ & $:$ & Carbon Dioxide \\
FGD & $:$ & Focus Group Discussion \\
GHG & $:$ & Greenhouse Gas Emissions \\
QSD & $:$ & Qualitative System Dynamics \\
TOE & $:$ & Ton Oil Equivalent \\
\hline
\end{tabular}

\section{Introduction}

The attempt to achieve a balance between economic growth and efforts to control climate change by reducing greenhouse gases (GHG) has to be undertaken

\footnotetext{
* Tel.: +62-816-77-4055

E-mail address: titi.putranti@gmail.com
}

simultaneously, although they could be seen to be contradictory. Economic growth supported by the roles of the industrial sector has to be synchronized with production growth and energy consumption. In the Indonesian case for example, on one hand, the government is concerned with using energy in the most efficient way possible to reduce emissions from energy consumption. On the other hand, the growth of energy consumption is likely to increase emissions from burning of fossil fuels.

The economic growth rate, coupled with increasing exploitation of natural resources, has directly and indirectly resulted in damage to the environment and ecosystems. Machado (2000) indicates that faster economic growth is always followed by increasing emissions, particularly carbon dioxide $\left(\mathrm{CO}_{2}\right)$ that results from production and consumption activities, as the industrial sector still relies on fossil energy. As the largest contributor to GHG emissions, $\mathrm{CO}_{2}$ has accounted for environmental pollution and climate change. In the long term, it could trigger a higher contribution of unestimated emissions through producer and consumer markets. In economic theory, this represents an externality of production and consumption activities as one of the forms of market failure.

Four industries that have produced the highest emissions in Indonesia are cement, iron and steel, textile, and pulp and paper (DNPI \& World Bank, 2009). The GHG National Action Plan (RAN GRK, 2011) has determined eight industries: cement, steel, pulp and paper, petrochemicals, fertilizer, ceramics, textile, and food and beverage which use large amounts of energy and produce high levels of emissions. A study by the Center of Administrative Studies of the Faculty of Social and Political Science, University of Indonesia (2013), shows broadly that $\mathrm{CO}_{2}$ emissions have increased at an alarming rate in the production sector over 1995-2010. Out of the ten sectors with higher elasticity, there are three sectors that have retained their elasticity over 1995-2010, which are chemical, heavy and cement industries. This means that increasing income of the community will raise $\mathrm{CO}_{2}$ from industrial activities of these sectors.

The Indonesian government has made a commitment to reduce GHG emissions by $26 \%$ up till 2020 . To support this commitment, the government issued Presidential Regulation number 61 of 2011 on the National Action Plan for Reduction of GHG Emissions. Nationally, the commitment was translated into the action plan (RAN GRK) and a similar emissions reduction program at the local level, Local Action Plan $(R A D)$. Although the RAN GRK indicates a small percentage of $3.12 \%$ to carbon emissions of the industries, the production and consumption activities of the industries remain reliant on fossil energy. In the long term, consumption of fossil energy can result in higher emissions unless the government makes appropriate strategies and guidelines to achieve the GHG reduction target in the 
industrial sectors. Unfortunately, the policy strategy defined in the RAN GRK aims only at energy auditing, particularly in energy consuming industries, and delivery of incentives through an energy efficiency program.

The target of GHG emissions reduction aims towards the outcome of slowing down climate change. However, a more important target may be the process to achieve sustainable development through compliance with the more comprehensive indicators of a green economy, which involve low carbon emissions, resources efficiency and social inclusiveness (UNEP, 2010). Following this approach, for other Asia-Pacific countries, particularly South East Asian countries, which are likely to suffer most from the impact of climate change, Crawford (2010) recommends a shift to low carbon development that can be done through low carbon industries. Industries need to combine shifts from carbon-intensive to knowledge-intensive sectors, focus on low carbon goods, infrastructure that supports low carbon transportation and a greater shift to energy-efficient manufacturing processes to reduce their carbon footprint (CCICED Annual General Meeting, 2011: 277).

Referring to these approaches, the challenge is how the government can intervene through direct and indirect policies for legal, economic, political and social initiatives as pull factors to realize low carbon industry. From the perspective of tax policy, tax could be made an important instrument or push factor to consider. However, there is as yet no tax policy that focuses specifically on encouraging low carbon industry. The apparent constraint to implementing this strategic step is that the Indonesian government has no definite guideline or roadmap for tax policy that is intended specifically to encourage low carbon industry.

Increasing industrial activities that rely on fossil energy could trigger higher contributions of emissions through producer and consumer markets. Governmental efforts are needed to enable transformation from high-carbon to lowcarbon industries. Such low-carbon industry would be one that succesfully runs its activities with a high level of resource efficiency and moves towards the use of new renewable energy $(E B T)$. The characteristics of low-carbon industry are industries that seek to: (i) reduce consumption of fossil energy; (ii) produce or use renewable new energy; (iii) use energy-efficient or low-carbon equipment; (iv) carry out waste management; (v) develop knowledge and technology through research and development for energyefficient technology and sources of renewable new energy.

According to Sidik (2011), industry generating substantial emissions (high-carbon industry) can be prevented in four ways, which are: “(1) production limitation, (2) internalization of externalities through waste treatment in respective industries, (3) tax imposition, (4) prohibition of any activity that might cause the foregoing externalities, or (5) a combination of these four alternatives." As an instrument of fiscal policy, tax policy could be either disincentive or incentive in nature (Bird dan Zolt, 2003).

As done in many countries to encourage investment and activities in low-carbon industry, the government in
Indonesia provides various tax incentives. However, many incentives that are fiscally equivalent to government subsidies from tax revenue do not seem to be sufficiently effective. Tax incentives currently given by the government are still limited to the sources of funding, capital, energy and raw materials, and they do not focus on encouraging low-carbon industry.

\section{Research Methods}

This research aims to evaluate the tax incentive policies that can encourage low-carbon industry in Indonesia. This research will try to: (1) Describe the condition of the current tax policy utilised to encourage low-carbon industry; (2) evaluate the current tax incentive policy that can promote low carbon industries in Indonesia; (3) Highlight the constraining factors and weaknesses of the tax incentive policy instruments towards low carbon industries; (4) Reconstruct a tax incentive policy towards implementing low-carbon industry.

This research uses a constructivist paradigm intended to carry out reconstruction of tax policy instruments that can encourage the implementation of low-carbon industry through the process of green industry. In the context of constructivism, the researcher has two key objectives, namely trying to define, to interpret (or portray) the meanings generated from the thoughts of sources on tax policy issues. Interpretation or definition of the research are based on the results of in-depth interviews and focus group discussions (FGD).

The approach used in this research is qualitative, using Qualitative System Dynamics (QSD). This qualitative research is intended to identify, explore and analyze data concerning tax policy at particular moments and in time series. Furthermore, the data are used to identify trends of tax policy in and from particular conditions. In this way, the data collected for the research serve as the basis for evaluation of tax policy instruments. QSD is the first phase of the system dynamics method. QSD can be used to address accessibility through using human control which enables various policy decisions to be investigated. The problem of determining tax policy with a qualitative approach will be oriented to employ versatile system thinking. The complexity and the reality of dynamic problems due to increased $\mathrm{CO}_{2}$ emissions affecting industry behavior are to be examined. QSD is the first phase of system dynamics. Wolstenholme (1989) as cited in White (2011) explains that System Dinamics is a method for qualitative description, exploration and analysis of complex systems including processes, organization structure and strategy. In Table 1 Wolstenholme divides System Dynamics into three parts. 
Table 1 System Dynamics Stage

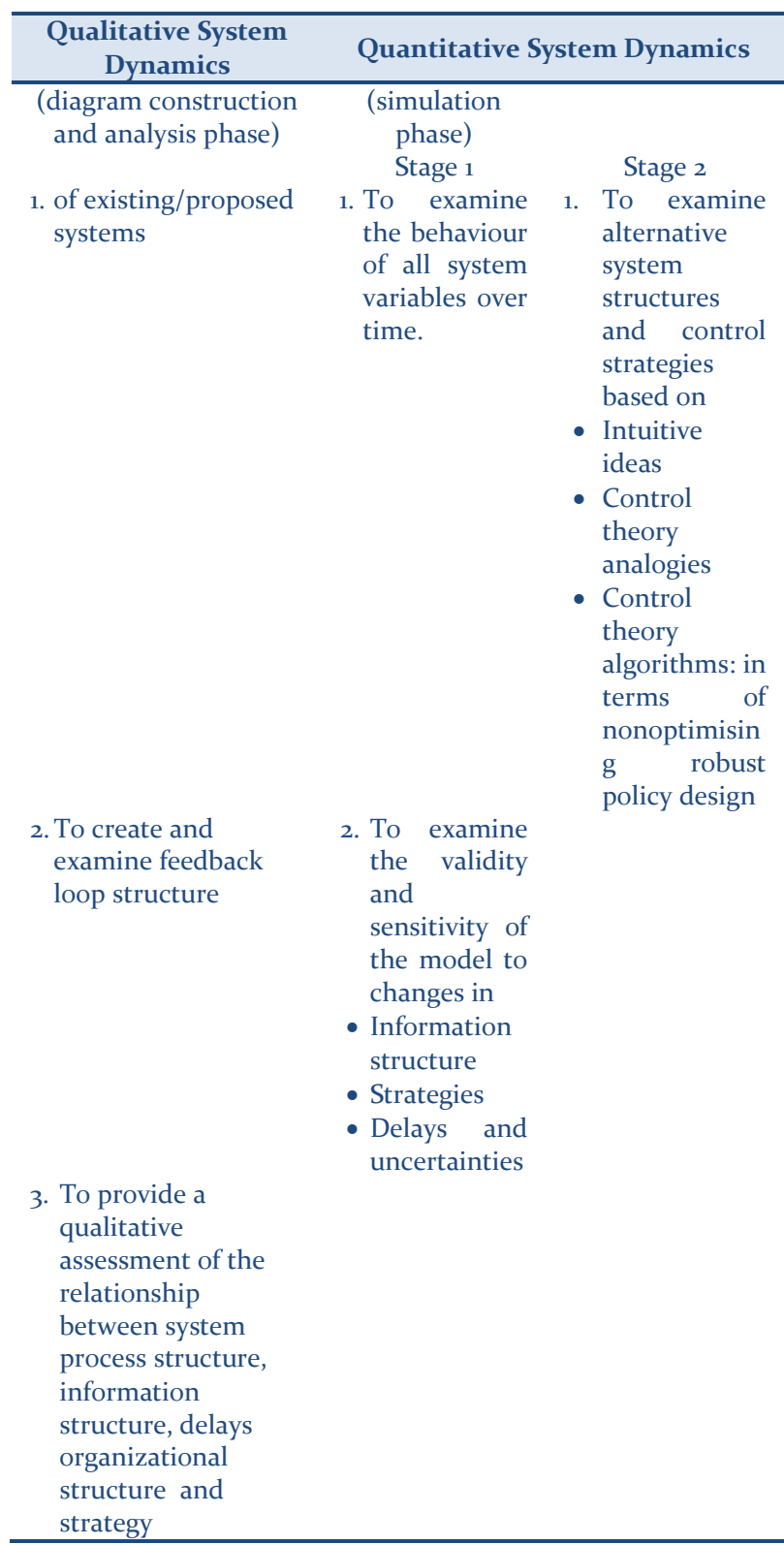

Source: Anthony S. White, 2011, Qualitative System Dynamics as a Tool in Accessible Design, Jurnal of Sofware Engineering asn Applications, 1. 69-8o.

\section{Results and Discussion}

The taxation laws and regulations, which are currently effective, do not specifically impose taxes on industries and manufacturers as an attempt to achieve low-carbon industry. All tax policies still aim at tax incentives that are spread and provided partially through various policies, and they do not specifically govern attempts to reduce GHG emissions and attain low-carbon industry. Inevitably, they seem trapped in sectoral needs and provide no comprehensive tax incentives that are conducive to reduction of GHG emissions.

\subsection{Conditions of Tax Policy for Current Industrial Activity}

The government's efforts through policies to encourage energy efficiency and shift to renewable energy can be implemented across a series of production and consumption processes. In industrial activity, efforts can be made through the sources of inputs that activate the industry and to the waste /residue of the industrial outputs. The sources of inputs that activate the industry include:

- Financial sources, including tax exemption, tax paid by government, capitals and loans

- Capital or principal goods such as equipment and machinery

- Human resources

- Energy to be used, which includes resources of fossil fuels and renewable energy

- Raw materials, including auxiliary materials

- Science and technology

- Information

The instruments of tax policy can also be mapped from categorization of business stages in each industry. The business stages (BKF, 2012:12) are as follows:

- Business start

- Energy input

- Non-energy input

- Business operation

- Waste management (gases/chemicals)

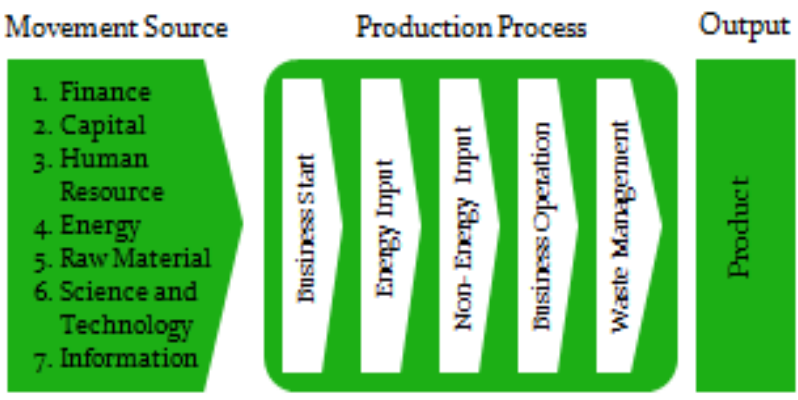

Figure 1 Processes in Industry

Table 2 shows the calculation of the current tax incentives, which are provided by the Ministry of Finance and reviewed from the perspective of industrial activating sources. 
Table 2 Spread of Tax Incentives in Industrial Processes

\begin{tabular}{|c|c|c|c|c|c|c|}
\hline $\begin{array}{l}\text { Industrial } \\
\text { Activating } \\
\text { Sources }\end{array}$ & $\begin{array}{l}\text { Busi } \\
\text { ness } \\
\text { Start } \\
\text {-up }\end{array}$ & $\begin{array}{l}\text { Ener } \\
\text { gy } \\
\text { Inpu } \\
\text { ts }\end{array}$ & $\begin{array}{l}\text { Non } \\
\text { Ener } \\
\text { gy } \\
\text { Inpu } \\
\text { ts } \\
\end{array}$ & $\begin{array}{l}\text { Busi } \\
\text { ness } \\
\text { Oper } \\
\text { ation }\end{array}$ & $\begin{array}{l}\text { Wast } \\
\text { e } \\
\text { Man } \\
\text { age } \\
\text { ment }\end{array}$ & Total \\
\hline Finance & 5 & 4 & & 5 & 1 & 15 \\
\hline Capital & 1 & 2 & 4 & & 1 & 8 \\
\hline $\begin{array}{l}\text { Human } \\
\text { resources }\end{array}$ & & & & & & $\mathrm{O}$ \\
\hline Energy & & 2 & & & & 2 \\
\hline $\begin{array}{l}\text { Raw } \\
\text { materials }\end{array}$ & 1 & & 4 & & & 5 \\
\hline $\begin{array}{l}\text { Science and } \\
\text { technology }\end{array}$ & & & & 3 & & 3 \\
\hline Information & & & & & & o \\
\hline Total & 7 & 8 & 8 & 8 & 2 & 33 \\
\hline
\end{tabular}

Based on the industrial activating sources, tax incentives given toward financial input ranks the highest, which includes 15 tax incentives. Next comes tax incentives that are given to capital sources (8), then there are 5 tax incentives for raw materials, and 3 for science and technology. Only 2 tax incentives are applied to energy as an industrial activating source, while no tax incentive is given to human resources and information. Based on the business stages, the stages of energy and non-energy inputs and business operation have the same number of tax incentives each (8). Then comes tax incentives for business start-up (7), business operation (5) and 2 kinds of tax incentive for waste management.

\subsection{Evaluation of the Current Tax Incentive Policy}

An evaluation is needed to identify the value of the current tax incentive policy. In line with Dunn's evaluation function (2003:609), the objective of evaluation of the tax policy performance is to determine a definite basis as the starting point for reconstruction of tax policy to encourage low carbon industry. This is based on the premise that having a complete picture of the current tax policy conditions will provide the reconstruction of tax policy with solid ground that begins with real conditions and corresponds to Indonesia's needs. Tax policy incentives can be said to be appropriate if they match the industrial needs and the conditions of the existing effective tax policy.

The results of interviews with key informants were mapped into a model. Figure 2 shows the evaluation model that was made for qualitative data using Nvivo 10. With the qualitative data, grouping was made based on the criteria of policy evaluation principles as suggested by William $\mathrm{N}$. Dunn (2003: 610) and the criteria of ideal taxation principles according to AICPA (2001: 7-8).

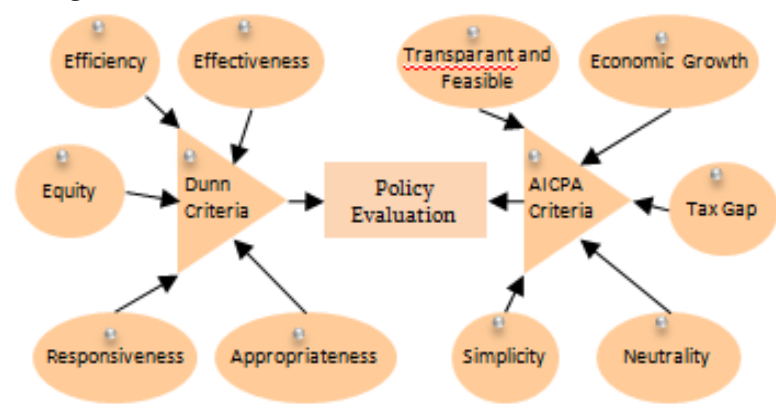

Figure 2 Model Resulting from Evaluation of Tax Incentive Policy

Not all of Dunn's evaluation criteria and AICPA's tax principle criteria were assessed using the results of the indepth interviews. Five of the ten ideal taxation criteria were extracted from discussions on the evaluation of tax incentive policy, which were: simplicity, neutrality, economic growth \& efficiency, transparency and visibility, and minimum tax gap. Administration of tax incentive delivery, which is not simple, has become the primary concern of businessmen. Industries do not consider the tax incentives to be neutral since the tax incentives offered by the Ministry of Finance discriminate against particular sectors, and the tax incentives are not attractive to the industry as they are uneconomical. The regulations are not transparent and the government's bureaucracy often makes delivery of the tax incentives difficult. The incentives for development of renewable new energy cannot compete with fossil energy due to difficulties in implementation.

From the foregoing evaluation of tax incentive policy and Dunn's perspective, tax incentive provision cannot be categorized yet as an alternative to attain low-carbon industry. From Dunn's perspective, the effectiveness should be anchored to the relationship between expected and real results. The expected result in this case is that the industries have shifted their activities from high-emission to lowemission activities, with the real results being reduced GHG emissions. This research did not measure GHG emission reduction that has been achieved, instead it focused on changes in production modes that enable lower emissions and higher GHG absorption (climate change mitigation) from emission sources.

Based on 9 categories of tax policy (without considering the subsidy category) that were adopted from the KMPG Green Tax Index 2013, the tax incentives offered by the Ministry of Finance have not yet introduced direct tax incentives for energy efficiency, carbon taxes, cap-andtrade, other carbon emission penalties, green building, water efficiency, pollution control and ecosystem protection. However, policies that might lead to energy efficiency, green building, water efficiency, pollution control $\&$ ecosystem protection can be developed by providing tax 
incentives that focus on the objectives of low-carbon industry.

\subsection{Constraints and Weaknesses in the Current Tax Incentive Policy}

The constraints and weaknesses, which the tax incentive policy has to deal with to encourage low-carbon industry, are chiefly: lack of coordination among the policy executors, lack of intensive measurement and benchmarking, no blueprint for industrial development, and policies that do not favour small domestic industries. These are discussed below:

\section{- Lack of Coordination among the Policy Executors} Implementation of a policy by government ministries or agencies at the operational level (Bromley, 1989) is the decisive stage in achievement of the final objectives of the policy, which are outputs (in the short term) and outcomes (in the long term). Therefore, coordination among related ministries or agencies is crucial to implementation of the tax incentive policy, but it is recognized that "coordination is the biggest obstacle in realizing policies in Indonesia (Yusuf, 2012). In fact, the operational level should lead to patterns of interaction between street-level bureaucrats and target groups that are substantially affected by the community's attitude and reaction (Bromley, 1989).

Experience from implementation of the tax incentive policy shows that there is hardly any coordination among the related ministries / agencies, and the role of a Coordinating Ministry of Economy seems to be highly needed. The President could enforce a policy for all ministries and agencies to make programs of unambiguous targets and definite indicators to enable tax incentive designs that correspond with industrial needs, but this is not the current practice.

- Intensive measurement and benchmarking is lacking Tax incentives provided by the government are closely related to the needs of industrial sectors, while sometimes the industries do not make the best use of the tax incentives. A study done by BKF and GIZ (2012) indicates that the tax value allocation, which is to be borne by the government in the national Budget (APBN) to enable adaptation to and mitigation of climate change, is not used at all by industries because no extensive socialization was undertaken by the government. Prioritisation of intensification of the socialization of the tax incentives is therefore required. One of the difficulties in absorbing tax incentives is the specification of goods that are given incentives, including the timeframe for the delivery of the incentives.

Generally, tax incentives are given to compliant tax payers. Article 1 of the Regulations of the Ministry of Finance number 192/PMK.03/2007 specifies tax paying entitiess matching particular criteria as being classified as Compliant Tax Payers. One of the requirements to be a compliant tax payer is that the entity has been audited by a certified public accountant for three years. The procedures set by the Ministry of Finance for the tax incentive facility are considered quite difficult by the Indonesia Association of Biofuel Producers (Apbrobi). The Ministry of Finance still finds it difficult to map out and measure appropriate tax incentive policy for industries. There are also constraints in measuring and determining correct tax incentives for development of industry of renewable new energy, and the tax incentives provided by the Ministry are not optimal yet.

- No Blueprint for Industrial Development

The government has nominally committed itself to the $26 \%$ targets of GHG emission reduction by 2020 , which implies that correct strategies and programs are then needed. The weakness of the Indonesian government in industrial sectors is that it has no blueprint for industrial development, specifically, nocomprehensive blueprint with linkage to all sectors. As a result, concern prevails that the $26 \%$ target of GHG emissions reduction will not be reached, since the there was still no measurable progress in 2011. Without a definite blueprint for the direction of tax incentive policy, the current tax policy is too weak to encourage low-carbon industry. RAN GRK represents a guideline for the government to carry out GHG emissions reduction, which could be supplemented with direction for the targeted tax incentive policy.

- Policies that do not favour Small Domestic Industries To encourage behavioural changes in the community towards energy efficiency and use of renewable energy, all parties from both public and private sectors have to have consistent perceptions of the GHG emissions reduction target in the industrial sector. While offered tax incentives might predispose businessmen to choose the objectives intended by the government, business drivers are more focussed on sustainable profit. Therefore, tax incentives should favour all industries that seek to make meaningful energy efficiency improvement and use of renewable new energy.

One of the examples that indicate non-preferential treatment of the government to small domestic industries is exemptions of value added tax (VAT) for import of capital goods (voltage regulators) for power generators, but the lack of tax exemptions for the purchase of the same capital goods (voltage regulators) in Indonesia. The government does not encourage purchase of voltage regulators that are domestic produced, and this has consequently pushed small businesses to import voltage regulators from out of the country and obtain the tax exemption. This policy is certainly of a contradictory nature, ademonstrating how economic growth is unsynchronized and incongruous. An important question that then arises is why import of capital goods is given VAT exemption while purchase of 
domestic products is not. This kind of discrimination would certainly lead to an assumption that the Ministry of Finance does not favour domestic small businesses.

\subsection{Reconstruction of Tax Incentive Policy, which can be Developed to Attain Low-Carbon Industry}

The reconstructive design of tax incentive policy with the intention to push industries towards energy efficiency and use of renewable energy and to realize low-carbon industry, should consider four aspects that are: the principle of tax incentive provision, forms of tax incentives, benefits of tax incentives, and requirements of tax incentives. The design of the the tax incentive policy reconstruction can be illustrated as follows:

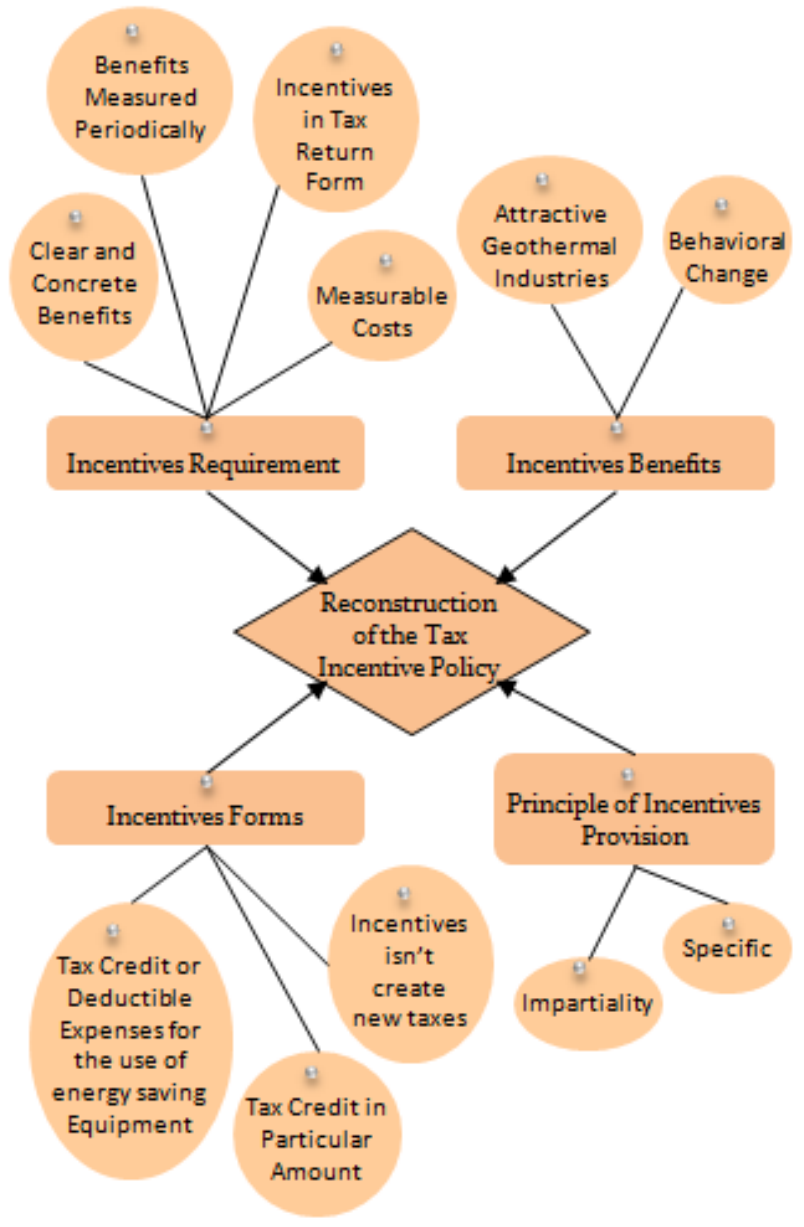

Figure 3 Design of the Tax Incentive Policy Reconstruction to Encourage Low-Carbon Industry

- Principle of Tax Incentive Provision

Tax incentive provision should comply with the principles of impartiality and specificity. Tax incentive provision should be of impartial nature that is, not given discriminatingly to one industrial sector only. Tax incentives should be specific for a particular objective.
Borrowing Brunori's argument (1997), tax incentives should be targeted to particular areas or activities, for example, the incentive is given to encourage the use of energy-efficient or low-carbon goods or equipment. If this particular equipment is used to lower emissions in the industrial sector, the industry may then earn the tax incentive. However, the weakness of the policy lies in the difficulty of determining whether or not the goods or equipment that are used are really meant for or capable of lowering carbon, or will be used for other broad objectives. Therefore, stringent control is needed in using goods or equipment that are given tax incentives.

\section{- Form of Tax Incentive}

Two basic decisions are needed when designing tax incentives, which relate to (i) investment types that are eligible and (ii) tax incentive forms that will be applied. There are several forms of tax incentive for investment, which include tax holidays, investment allowances and credits and tax credits. However, as shown by previous research, no country has adopted the tax credit approach for this area (Zolt, 2014:15). The forms of tax incentive could be tax incentive addition to those currently provided by the Ministry of Finance. Targeted tax incentives could consider the following policies: (i) investment credits, (ii) deductible expenses and (iii) tax incentives that are provided by not imposing a new tax, such as a carbon tax.

The concept of investment credits or tax credits is similar to investment allowances. Investment allowances and credits can be transformed into other alternatives or sometimes additional incentives from tax holiday provisions (Zolt, 2014:16). If investment allowances reduce taxable income, tax credits will then reduce outstanding income tax. The allowable tax credits can be computed as particular percentages of all paid expenses. The expenses, as the basis for calculation of tax credits, can be limited to particular categories or activities that characterize low-carbon industry. The tax credit percentage can be added for activities of environmentally friendly nature for a particular timeframe. Deciding the amount of allowable tax credits is therefore crucial, and tax credit had better be given only once to industry that is eligible as low-carbon industry. Deductible expenses from gross income for calculation of taxable income, which has so far been regulated by Article 6 of the Law of Income Tax, can be expanded especially for industries that meet the requirements to be low-carbon industries.

For now, the appropriate form of incentive that is given is oriented more to provision of tax incentives, not imposition of new taxes such as a carbon tax. Within the context of carbon tax collection, it is not in the framework of tax incentives, rather it is imposition of new tax that is different from income tax. Any tax collected for and related to the environment is an 
environmental tax that is considered to be different from other taxes.

- Benefits of Tax Incentive

The benefit of a tax incentive in this context is mainly for encouraging behavioural changes in industrialists towards energy efficiency. The behavioural change should ideally become a national agenda that does not merely follow the global agenda. Although it is known that climate change is a global issue, both impacts and actions should be considered at the regional and local levels to be the agenda of the Indonesia community. Tax incentives that are intended to change behaviours of industries can improve Indonesia's leverage in international fora. Such behavioural change can be shown by changes in technology and habits to use energy more efficiently. The other benefit of tax incentive provision is to attract investment in renewable energy. Article $31 \mathrm{~A}$ of the Law of Income Tax gives several tax incentives, which investors in renewable energy might find attractive. Although known, not all renewable energy industries are given specific incentives. For example, there is no incentive for the geothermal industry, which will make the industry difficult to expand in Indonesia. The long term impacts of environmentally friendly industrial activities will likely help reduce carbon emissions and reach the GHG reduction target. This successful low-carbon attainment would demonstrate that the government's tax incentive intervention has paid off.

- Requirements of Tax Incentive Provision

If necessary, tax incentive policy should be accommodated in related taxation law in order that the Directorate General of Taxation as the executing agency finds it easy to carry out. Therefore, consideration should be given to the requirements for tax incentive provision and the implementation administration.

To the state, tax incentive provision has to be clear, concrete, regularly measurable and renewable. Therefore, there has to be cost benefit analysis of financial, economic and social aspects. Tax incentive policy has to be regularly measurable and renewable, and tax incentive provision also affects the implementing administration. Therefore, tax returns have to be adjusted to accommodate delivery of tax incentives. The current taxation laws and regulations do not yet include definite articles on incentive types, application procedures and incentive delivery. This shows that, in addition to no focused mapping of tax incentive, the implementation instruments have not been prepared yet.

The results of the reconstruction of tax incentive design can be translated into a package of tax policy, which focuses on encouragement of low-carbon industry. The tax incentive package can be given to industries that are categorized as illustrated in Figure 4 and Table 3.

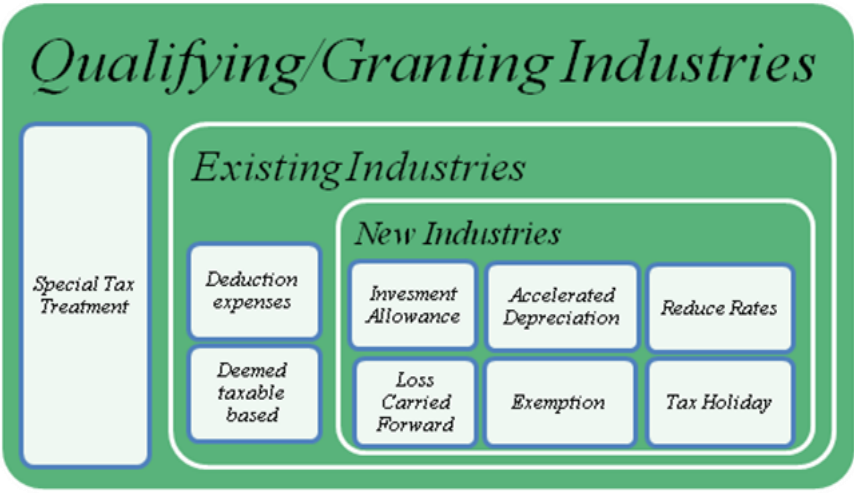

Figure 4 Industry Categories Based on Received Tax Incentive

Table 3 Tax Incentive Types Based on Industry Categories

\begin{tabular}{|c|c|c|c|}
\hline Tax Incentives & $\begin{array}{c}\text { New } \\
\text { Industries }\end{array}$ & $\begin{array}{l}\text { Existing } \\
\text { Industries }\end{array}$ & $\begin{array}{c}\text { Alternatives } \\
\text { for } \\
\text { Qualifying } \\
\text { Industries }\end{array}$ \\
\hline $\begin{array}{l}\text { Investment } \\
\text { Allowance }\end{array}$ & * & & \\
\hline $\begin{array}{l}\text { Accelerated } \\
\text { Depreciation }\end{array}$ & * & * & * \\
\hline Reduce rates & * & * & * \\
\hline $\begin{array}{l}\text { Loss } \\
\text { forward }\end{array}$ & * & * & * \\
\hline $\begin{array}{lr}\text { Exemption/ } & \text { Tax } \\
\text { borne } & \text { by } \\
\text { government } & \end{array}$ & * & * & * \\
\hline Tax holiday & * & * & \\
\hline Deduction expenses & & * & * \\
\hline $\begin{array}{l}\text { Deemed taxable } \\
\text { base }\end{array}$ & & * & \\
\hline Special Tax & & & \\
\hline $\begin{array}{l}\text { Treatment in } \\
\text { Tax Credit } \\
\text { Provision }\end{array}$ & & & * \\
\hline
\end{tabular}

\section{New Industries}

Currently, the Ministry of Finance provides various tax incentives for industries that have newly invested their capital. Tax incentives are also given to tax payers that have invested their capital in particular business lines and / or certain regions, including uses of new sources of renewable energy. These incentives are income tax incentives that include:

- Investment allowance that amounts to $30 \%$ of investment value and is effective for six years, or $5 \%$ per year;

- Accelerated depreciation and amortization;

- Income tax imposition on dividend that is paid to overseas tax payers, which amounts to $10 \%$, or lower tariff as defined in the effective Agreement of Double Tax Evasion (reduced rates of withholding tax on remittances to the home country);

- Loss compensation (loss carried forward), which is longer than 5 (five) years but shorter than 10 (ten) 
years;

- Income tax exemption as defined in Article 22 for import of machinery and equipment, built up or knocked down but excluding spare parts, which are needed by entrepreneuers to use sources of renewable energy;

- VAT exemption for import of taxable goods of strategic nature such as machinery and equipment, built up or knocked down but excluding spare parts, which are needed by entrepreneur to use sources of renewable energy and to produce taxable goods;

- These tax incentives can be used for both new capital investment and expansion of existing business in order to improve product quantity / quality, diversify products or expand operational areas. These tax incentives can also be used by new industries that have made investment in economic sectors, which are considered high priority at national and local scales and have potentials that are feasible to develop. These tax incentives also apply to particular business lines, including basic metal, textile, pulp and paper industries, and to particular business lines and regions including cement, lime and gypsum industries.

- Customs duty exemption for import of machinery, goods and materials, which is undertaken by companies that run:

- Industry to produce goods; and / or

- Industry to provide services [such as tourism and culture, transportation (for public transportation service), public health service, mining, construction, telecommunication, harbour affairs];

- The Ministry of Finance also provides income tax exemption or deduction for corporate bodies, for 5-10 years as of tax year of commercial production start. This tax facility is tax holiday, which means provision of tax exemption or deduction for particular timeframe. This tax facility is also given to pioneering industries, which are industries that have extensive linkages, give higher added value and externalities, introduce new technology, and have strategic value for national economy. They include:

- Basic metal industry;

- Industry of natural oil refinery and basic organic chemicals that are made of natural oil and gases;

Machinery industry;

Industry of renewable resources; and / or

Industry of telecommunication equipment.

The tax holiday can certainly benefit new and pioneering industries. Included in this category are pioneering industries that use new technology to produce goods, including renewable energy and environmentally friendly activities. This policy can be categorized as green policy that can be used to encourage low-carbon industries.

\section{Existing Industries}

Currently, tax incentives are also given to industries that include manufacturing industries, which are indicated as generating the highest GHG emissions. To encourage these industries to shift to low-carbon industries, tax incentives that are given include:

- The industries may have loss carried forward, which is longer than 5 (five) years but shorter than 10 (ten) years, for the costs of research and development. Oneyear addition is included if the research and development expense is made in Indonesia for product development and production efficiency, which amounts to at least $5 \%$ of investment in five-years time.

- To develop industries that produce goods, the tax incentives are extended to custom duty exemption for machinery import in two to five years. Custom duty exemption is also given to import of goods that are factually used in the upper reaches of oil, natural gases and geothermal businesses, including goods that are imported and used by the industries to treat waste and control environmental pollution.

- Sales Tax on Luxury Goods with Taxable Based of o\% of sale price (Deemed VATable based), for motored vehicles of affordable prices that are included in the energy-efficient car program.

- VAT to be borne by government for import of goods that are used in the upper reaches of oil, natural gases and geothermal exploration businesses by entrepreneur of oil and gas upper reach activities or geothermal activities.

- Additional tax holiday in the form of more deductible income tax by $50 \%$ of outstanding income tax in two tax years. This is given to pioneering industries that have extensive linkages, give higher added value and externalities, introduce new technology, and have strategic value for the national economy.

- Deducted expenses for calculation of taxable incomes, as defined in Article 6 of the Law No. 36 of 20o8. These expenses relate directly and indirectly to business activities, including waste treatment cost, research and development expenses that are made in Indonesia, donation for research and development done in Indonesia as defined by Government Regulation. Particularly related to stipulations of research and development expenses that are made in Indonesia, the amount of the expenses has to be reasonable to find new technology or systems for company development.

\section{Qualifying/Beneficiary/Granting Industry}

The design of reconstruction of the tax incentive policy can be expanded to make industries try environmentally friendly (green) innovation. Development of science and technology innovation, which results from research and development activities, is believed to be able to prompt the industries to produce renewable energy and use the energy for environmentally friendly production activities. Special 
tax treatment in the form of tax credit can be given to these two types of industry, which may be categorized as qualifying / beneficiary / granting industries.

However, to-date, tax incentives for industrial activating sources, such as science and technology, have not been focused on research and development for low-carbon industry. Presidential Regulation No. 28 of 2008 , on national industrial policy that sets the guideline for national industrial development, has indicated facility provision for industries that preserve the living environment and embark on research, development and innovation. The facility consists of fiscal and non-fiscal incentives. Internationally, the only mechanism for non-Annex I countries to follow, based on Kyoto Protocols, has been the Clean Development Mechanism (CDM), although technological transfer from advanced countries is not easy to attain. Therefore, independent development of technological innovation should be promoted by the government through provision of appropriate tax incentives. Tax incentives for development of environmentally friendly innovation can be provided for existing industries to make them become qualifying / beneficiary / granting industries.

Development of environmentally friendly technology is an important activity of research and development. Factually, 18 out of 21 countries analyzed in the report of the KMPG Green Tax Index 2013 use their taxation system to encourage the research and development. A study by Hall and Reenen (2000) lists R\&D definitions that are specialized for having tax credit in a number of countries of the world. $R \& D$ is defined as patent, development, improvement, software, including software experimentals, some testing, improvement of valuable inventions, and scientific research development of technology.

Taxation treatment for R\&D expenses made by companies has been governed by Article 6 of Law No. 36 of 2008. The deductible expenses for calculation of taxable income are those that relate directly or indirectly to business activities, including R\&D expenses that are made in Indonesia and donations for R\&D done in Indonesia as defined by Government Regulation.

Therefore, tax incentives related to R\&D expenses can actually be developed and focused on efforts to develop lowcarbon industry, given the fact that there is as yet no tax incentive that is specifically provided for development of science and technology through research and development. Technological innovation is important to develop machinery or other assets for production that meet the environmentally friendly criteria, thereby giving added value for production of the sources of renewable energy. The criteria for tax incentive provision can include several conditions, among others, asset lists (of particular technology) that can be used to produce sources of renewable energy when proposing an investment. Incentive provision can also involve percentages of investment or profit values.
Several criteria used when designing tax incentive policy, for scientific and technological development through $\mathrm{R} \& \mathrm{D}$, should consider the following points:

- Definition of relevant R\&D and their limitations;

- Justification of R\&D cost that is given tax incentive;

- Entrepreneurs who are eligible to have tax incentives for R\&D, including terms and conditions for medium and small businesses;

- Types of offered tax incentives;

- R\&D activities that are given tax incentives, such as those that are undertaken continuously using new science and technology (including humanity and social sciences) and likely to result in new production methods and quality products. Of course, this includes scientific and technological developments to make raw materials of renewable energy.

- Definition of cost / expense categories that relate directly to R\&D projects;

- Definition of documents and procedures that entrepreneur must utilise to get the tax incentive facility, such as R\&D proposal and budget, the experts, and formulae that are used;

- Definition of the types of technological areas, which form parts of the requirements to obtain the tax incentives, such as technology for sources of renewable energy and energy conservation, resource and environment technology, new technology of quality for innovation of traditional industry, including creative industry;

Tax policy can aim at provision of tax incentives for scientific and technological research and development. As an activating source of industrial processes, science and technology are able to produce innovation in products that have added value. This idea strengthens the proposed conception of raw materials for renewable energy, which is based on added value. Transformation of economic growth to green industry needs to be done by encouraging changes from raw materials and activities of low added value to those driven by environmentally friendly innovation through scientific and technological research and development. This basic idea conforms to that of Salim (2012) that "the current development trend is green growth that is characterized by the uses of raw materials of renewable new technology. Development also means increased revenue through VAT that is imposed on renewable resources, supported with incentives for the science and technology." Tax incentive provision will enable increase in demand for renewable energy and thriving of environmentally friendly industries, hence potential revenue from VAT. In the long term, uses of resources such as coal and non-renewable energy will slowly die down. "Emission reduction represents a product of maximum use of renewable energy, which also generate added value and new job opportunities. There will be many new job opportunities offered, and it is these opportunities 
that promote a sustainable economy" (interview with Mathias Rhein, 2012).

The design of the tax incentive policy reconstruction will consider provision of tax incentives for three categories of industry, which are new industries, existing industries and industries that are eligible to have additional facilities (qualifying/beneficiary/granting industries), for all activating sources of these industries. This includes tax incentives for each business stage, from the start-up, energy and non-energy inputs, business operation and waste management (gases and chemicals). The ideal design of the tax incentive policy reconstruction for these three categories of industry should take account of tax policy aspects, including related tax policies and laws as well as tax administration aspects to enable smooth implementation.

\section{Conclusion}

Tax incentives to encourage low-carbon industry in Indonesia are still insufficient and poorly oriented, spread and not focused on the efforts to reduce GHG emissions from industrial sectors. The tax incentive policy is therefore considered ineffective as a factor that helps realization of low-carbon industry. Evaluation of five criteria of taxation principles has drawn conclusions that: (i) administration of the tax incentive provision is considered complicated and has become a primary concern of many industrialists; (ii) the tax incentives are not neutral, which mean that they discriminate against particular activities in a certain period. Special tax incentives offered by the Government have affected decisions of tax payers, who choose not to take the tax incentives; (iii) Tax incentives for development of renewable energy cannot compete with fossil energy and are not attractive to industries on account of their being uneconomical; (iv) Unclear tax regulations and government bureaucracy have impeded delivery of the tax incentives and encouragement of low-carbon industry. This includes lack of coordination among the policy executors, no intensive measuring and no blueprint for industrial development, hence making the tax intensive policy difficult to measure accurately. The tax incentive policy tends to disfavour domestic small and micro industries.

The design of the tax incentive policy reconstruction, which is meant to encourage changes in industrial behaviour towards energy efficiency and uses of renewable energy, should consider four aspects that are the principle of tax incentive provision, forms of tax incentive, benefits of tax incentives and terms and conditions to have tax incentives.

- Tax incentives are not to be given in discriminating manners to only one sector, but to be provided in a specific way for particular objectives and not generalized;

- The targeted tax incentives can be added to, for example, (i) investment credit, (ii) deductible expenses, and (iii) currently no imposition of new taxes (carbon tax);
- The benefit of the tax incentive provision is intended to make substantial changes in behaviour of industrialists for energy efficiency and to attract investment in renewable energy; and

- The terms and conditions of the tax incentive provision must be made clear and concrete, with costs being measurable on a regular basis and with the Tax Notification Letter (SPT) considering items that are eligible for the tax incentive provision.

The reconstruction design also considers tax incentive provision for industries that are eligible to have additional facilities (qualifying/ beneficiary/ granting industries), through special tax treatment.

Several points that can be taken into consideration by the government in designing tax incentive policies for the entire industry that has the characteristics of low-carbon industry.

- Tax incentive policies to encourage behavioral change in the industry towards energy efficiency and switch to renewable energy must be designed in a focused way. This can take the form of a comprehensive measures package from the Ministry of Finance which includes Income Tax, Value Added Tax and Customs policy. The tax policy package aimed at addressing the high carbon emissions from industry, which is not friendly to the environment and have a negative impact on climate change. As an implementation of the tax policy package, the Minister of Finance can undertake strategic steps by publishing the Minister of Finance Regulation which comprehensively aims to provide stimulus to economic actors for energy efficiency and switch to renewable energy.

- Tax policy should be designed to promote the principles of an ideal tax. Administrative implementation of tax incentives should only require $t$ easy and simple to prepare application procedures. The process of application up to acquiring the tax incentives should be done within a short time frame, especially if this process is equipped with appropriate information technology systems. Information distribution and publication on tax incentives should be carried out continuously.

- The policy package of tax incentives should be taken as a priority and have the attention (concern) of all ministries or government agencies. The tax incentive policy package is structured as a product of group consensus policy and not merely satisfaction of sectoral needs. It can take the form of a kind of a joint decree binding across ministries. Therefore, the coordination between the implementors of policies should be in line with the goal to reduce GHG emissions. The blueprint of industrial development must be equipped with clear targets so that tax incentives can also calculate costs and benefits. The government should have a standard or baseline of GHG emitters from each sector. Because the appropriate tax incentives must be based on precise 
measurements. Tax policy instruments can be counterproductive when there is no coordinated commitment from all sectors, especially in the measurement of the standard as the basis for calculating the tax incentives.

- The Model of tax incentives that can be offered is to develop the existing tax incentives or to add special treatment such as tax credits which are calculated as a certain percentage, and can reduce the payable income tax. In terms of administrative supervision it is easier to grant tax credits as long as the required data can be provided within the means of reporting a tax return or other submission form that were properly designed.

- The tax incentives offered should be enjoyed by small industries or small and medium micro enterprises in the country to develop the innovation of renewable energy technologies. Tax incentives can generate a program with a double advantage (double dividend). Tax incentives can influence behavior patterns of people to reduce GHG emissions, and tax revenues are believed to be recoverable (recapture) through other tax revenues, such as the Value Added Tax receipts from the production and consumption of cheaper renewable energy.

Despite the implementation of a carbon tax continuing to be debated, alternatives for the purpose of encouraging low-carbon industry are possible..

\section{Acknowledgements}

I thank to Maria Tambunan, Nidaan Kafian, Neni Susilawati, Handry Imansyah, Afrah Ar-Rumaisha', Jona Widagdo, for helpfull comments on an earlier draft and Prof. Gunadi, Prof. Haula Rosdiana for their review.

\section{References}

[1] Ågerup, Martin, at,al. Climate Change And Sustainable Development, A Blueprint From the Sustainable Development Network, London: International Policy Network; 2004.

[2] Anthonie, Robert. Tax Incentives For Private Investment in Developing Countries, Netherlands: Kluwer; 1979.

[3] Bird, Richard M dan Eric M.Zolt. Introduction to Tax Policy Design and Development, Washington: Word Bank; 2003.

[4] Bluffstone, Rendall A. Environmental Taxes in Developing and Transition Economics. Departemen of Economics University of: 219-221.

[5] Boadway Robin W dan David E. Wildasing. Public Sector Economics. Second Edition, Toronto: Little, Brown and Company; 1984.

[6] Brown C.V dan P.M.Jackson. Public Sector Economic. 3rd edition, Great Britain: Brown, C.V.; 1986.

[7] Bromley, Daniel W. Beyond. Market Failure: Volitional Pragmatism as a New Theory of Public Policy. Economica Politica/a.XXV, n.; 2008

[8] Brunori, David. Principles of Tax Policy and Targeted Tax Incentives. State and Local Government Review; 1997,Vol.29, No.1.

[9] Chan, Samuel Y.S., dan Daniel K.C. Cheung. Tax Policy on Research and Development - Experience form China's Tax
System. International Tax Journal.; 2010: November-December 2010. Redlands.

[10] Chen, Yihsu dan Chung-Li Tseng.Inducing Clean Technology in Electricity Sector: Tradable Permits or Carbon Tax Policies?.The Energy Journal.; 2011:Vol. 32, No. 3.

[11] Cooper, Richard N. International Approaches to Global Climate Change. The World Bank Research Observer; 20oo,Vol. 15, No. 2.

[12] Crawford, Jeffrey. Low Carbon Green Growth: Integrated Policy Approach to Climate Change for Asia-Pasific Developing Countries, UN ESCAP.

[13] Deloitte. 2013 Global Survey of R E D Tax Incentives.;2013.

[14] Devereux, Michael P., Editor. The Economics of Tax Policy, New York : Oxford University Press; 1996.

[15] Dunn, Willian N. Public Policy Analysis: An Introduction, Second Edition, translation Yogyakarta: Gajah Mada University Press; 2003.

[16] Edwards, George C. Implementing Public Policy. Washington DC: Congresional Quarterly Press; 1980.

[17] Easson, Alex. Tax Incentives For Foreign Direct Investment, Netherlands, Kluwer Law International; 2004.

[18] Gandhi, Ved P. Supply-Side Tax Policy: Its Relevance to Developing Countries. Washington, D.C.:IMF; 1987.

[19] Gordon, Richard K. and Victor Thuronyi. Chapter 1, Tax Legislative Process, dalam Victor Thuronyi, Tax Law Design and Drafting. volume 1, ed., New York: International Monetary Fund; 1996.

[20]Hall, Bronwyn dan John Van Reenen. How effective are fiscal incentives for RED? A review of the evidence. Research Policy 2; ,200o. www. Elsevier.nl/locate/econbase.

[21] Hancock, Dora. Taxation: Policy and Practice, Thomson Business Press; 1997.

[22] Howlett, Michael dan M Ramesh. Studying Public Policy: Policy Cycles and Policy Subsystems, New York: Oxford University Press; 1995.

[23] Indonesia Energy Outlook 2010. Pusat Data dan Informasi ESDM, Jakarta, Kementrian ESDM; 2010.

[24]Jha, Raghbendra. Fiscal Policy in Developing Countries: A Synoptic View. ASARC Working Paper o1; 2007.

[25] Kato, Takatoshi. Fiscal Policy Instruments and Climate Change. Journal Efficiency of Public Spending Word Bank; 2007: http://web.worldbank.org.

[26]Kates, Robert W, Thomas M. Parris, and Anthony A. Leiserowitz. What is sustainable development? Goals, Indikators, Environment: Science and Policy for Sustainable Development"; 2005, Volume 47, Number 3, April.

[27] Labre, Marcelo; Atkinson, Colin. On the pricing of Emission Reduction Purchase Agreement contracts. The Journal of Energy Markets; 2010,Vol 3, Number 2, p. 69-VI

[28] Le, Tuan Minh. Value Added Taxation: Mechanism, Design, and Policy Issues, Paper on Practical Issues of Tax Policy in Developing Countries, World Bank, Washington D.C.; 2003.

[29] Lu, Zhen, Geoff Cockfield dan Yahua Zhang. The Effectiveness of Using Carbon Tax to Reduce Carbon Emission in China: Evidence from a CGE Model; 2011.

[30]Mankiw, N.Gregory. Pengantar Ekonomi, Edisi Kedua Jilid 1: Jakarta, PT Gelora Aksara Pratama; 2001.

[31] Mansury, R. Kebijakan Fiskal, Jakarta: Yayasan Pengembangan dan Penyebaran Pengetahuan (YP4);1999.

[32] _. Pajak Penghasilan Lanjutan, Jakarta: Ind Hill-Co; 1996.

[33] Mangkoesoebroto, Guritno. Ekonomi Publik, Yogyakarta: BPFE Yogyakarta; 1993. 
[34] Marsuni, H Lauddin. Hukum dan Kebijakan Perpajakan di Indonesia, Yogyakarta: UII Press; 2006.

[35] Marshall, Catherine dan Gretchen B. Rossman. Designing Qualitative Research, London: Sage Publication;1989.

[36] Mas'oed, Mohtar dan Riza Noer Arfani dalam Fatkurrohman. Pemanasan Global dan Lubang Ozon: Bencana Masa Depan, Jogyakarta: Media Wacana; 2009.

[37] McEachern, Willian A. Economics: a Contemporary Introduction, terjemahan, Jakarta: Penerbit Salemba Empat; 2002

[38] Metcalf, Gilbert E dan David Weisbach. The Design of a Carbon Tax. USA, Harvard Environmental Law Review; 2009.

[39] Milne, Janet E.Carbon Tax in the United States: The Context for the Future. Vermont Journal of Environmental Law; 2008,Vol 10.

[40]Mitchell, B., B. Setiawan dan Dwita Hadi Rahmi. Pengelolaan Sumberdaya dan Lingkungan. Yogyakarta, Gadjah Mada University Press;2003.

[41] Murdiyarso, Daniel. Sepuluh Tahun Perjalanan Negosiasi: Konvensi Perubahan Iklim, Jakarta: Buku Kompas;2003.

[42] Musgrave, Richard A dan Peggy B Musgrave. Public Finance in Theory and Practice, terjemahan, Jakarta: Penerbit Erlangga; 1993.

[43] Nehring Asociates, Traversing the Mountaintop. World Fossil Fuel production to 2050, Philosohical Transaction of the Royal Society. 675 Southpointe Court, Colorado Spring, United States.

[44]Neuman, W. Lawrence. Social Research Methods: Qualitative and Quantitative Approaches, Sixth Edition, Boston: Pearson Education, Inc.; 2006.

[45]Noor, Henry Faizal. Ekonomi Manajerial, Jakarta: PT Raja Grafindo Persada;2007.

[46]Oates, Wallace E. Green Taxes: Can We Protect the Environment and Improve the Tax System at the Same Time?. Southern Economic Journal; 1995,Vol. 61, No.4, April, 1995, http://www.jstor.org/stable/1060731.

[47]OECD. Frascati Manual 2002, Proposed Standard Practice for Surveys on Research and Experimental Development, 6th edition, Paris: ISBN 92-64-19903-9; 2002.

[48]_Main Definitions And Conventions For The Measurement Of Research And Experimental Development (RED): A Summary of The Frascati Manual 1993, Paris; 1994.

[49]Parikh, Kirit. Sustainable Development and the Role of Tax Policy. In: Asean Development Review, Studies of Asian and Pacific Economic Issues, ADB.;1995, Vol. 13 No.1.

[50]Prince, Lynne, Christina Galitsky, Jonathan Sinton. Tax and Fiscal Policy for Promotion of Industrial Energy Efficiency: A Survey of Internasional, The Energy Foundation's China Sustainable Energy Program;2005.

[51] Putranti, Titi Muswati. Tax Policies on Certified Emission Reduction Transactions. International Journal of Administrative Sciences \& Organization, Bisnis \& Birokrasi. Depok, 2011,Vol.18, No.3.

[52] Richard M Bird dan Eric M. Zolt. Introduction to Tax Policy Design and Development, Paper on Practical Issues of Tax Policy in Developing Countries. Washington. Word Bank; 2003.

[53] Rusbiantoro, Dadang. Global Warming for Beginner: Pengantar Komprehensif tentang Pemanasan Global, Yogyakarta;2008.

[54]Robinson, John, at.al. Climate Change and Sustainable Development: Realizing the Opportunity. Ambio; 2006, Vol. 35, No.1, p.3 http://www.jstor.org/stable/4315675

[55] Rosdiana, Haula dan Edi Slamet Irianto. Pengantar Ilmu Pajak: Kebijakan dan Implementasi di Indonesia, Jakarta: Rajawali Pers;2012.
[56]Rosdiana, Haula. Implikasi Perluasan definisi Royalti Terhadap Industri Telematika. Jurnal Ilmu Administrasi dan Organisasi, Bisnis \& Birokrasi; 2006,Vol.14, No.3.

[57]__ Rekonstruksi Konsepsi Supply-Side Tax Policy. Jurnal Ilmu Administrasi dan Organisasi, Bisnis \& Birokrasi,;20o8. Vol.15, No.3.

[58]Rose, Jeremy. Interaction, transformation and information systems development - an extended application of Soft System Methodology. Journal Information Technology \& People; 2002.

[59]Seidman, Laurence S. Public Finance, Singapore: McGraw Hill International Edition; 2009.

[6o]Sathaye, Jayant, P.R.Shukla dan N.H.Ravindranath. Climate change, sustainable development and India: Global and national concerns. India: Current Science; 2006,Vol.9o, No. 3.

[61] Smith, Adam. An Inquiry into the Nature and Causes of the Wealth of Nations, New York: The Modern Library Edition; 1994.

[62] Smith, Dan Throop and James B Webber, and Carol M Cerf. What you should know about the VAT, Illinois: Down JonesIrwin Inc.;1973.

[63] Steinmo, Sven. Tax Policy, USA, Edward Elgar Publishing, Inc.; 1998.

[64]Stern, Nicholas Herbert. Stern Review: The Economics of Climate Change, Great Britain Treasury; 2007.

[65]UNEP. Green Economy Indicators. Briefing Paper; 2012.

[66]UNEP. Towards a Green Economy, Pathways to Sustainable Development and Poverty Eradication, France: UNEP; 2011.

[67]UNIDO. UNIDO Green Industry Initiative for Sustainable Industrial Development, Vienna: UNIDO; 2011.

[68]UNIFO. UNIDO Green Industry: Policies for Supporting Green Industry, Vienna: UNIDO; 2011.

[69]United Nations Environment Program, Green Economy, Why a Green Economy Matters for the Least Developed Country, Kenya: UNEP Publish

[7o]United Nation Economic and Social Commission for Asia and the Pacific (ESCAP). Low Carbon Green Growth Roadmap for Asia and the Pacific: Turning Resource Contraints and the Climate Crisis into Economic Growth.Working Paper Series; 2012, April 2012.

[71] UNDP. "Sisi Lain Perubahan Iklim: Mengapa Indonesia Harus Beradaptasi untuk Melindungi Rakyat Miskinnya", Jakarta; 2007.

[72] Viherkentta. Tax Incentives in Developing Countries and International Taxation, Netherlands, Kluwer Law and Taxation Plublishers;1991.

[73] Weisbach, David. Instrument Choice is Instrument Design. Paper; 2010. ISBN:978 o 52119668 o, August.

[74] White, Anthony S. Qualitative System Dynamics as a Tool in Accessible Design. London: Journal of Software Engineering and Applications, 2011, Vol. 1, 69-8o.

[75] Wells Jr, Louis T, Nancy J. Allen, Jacques Morisset and Neda Prinia. Using Tax Incentives to Compete for Foreign Investement, Are They Worth the Cost?, Washington DC, The International Finance Corporation and the World Bank; 2001.

[76] World Bank. "World Development Report 2010, Development and Climate Change." World Bank, Washington, DC.; 2010.

[77] Yihsu Chen dan Chung-Li Tseng. Inducing Clean Technology in Electricity Sector: Tradable Permits or Carbon Tax Policies?. The Energy Journal; 2011, Vol. 32, No. 3

[78] Yonah, Reuven S. Avi dan David M Uhlmann. Combating Global Climate Change: Why a Carbon Tax is a Better Response to Global Warning than Cap and Trade. Michigan Law: Public Law and Legal Theory Working Paper Serries; 2009, No. 117. 
[79]Yusuf, Arief Anshory. The Distributional Impact of Environmental Policy: The Case of Carbon Tax and Energy Pricing Reform in Indonesia. Research Report; 2008, No.2008RRI, Singapore: The Economy and Environment Program for Southeast Asia (EEPSEA).

[8o]Zhen Lu, Geoff Cockfield dan Yahua Zhang. The Effectiveness of Using Carbon Tax to Reduce Carbon Emission in China: Evidence from a CGE Model.

[81] Ahmad, Mubariq.Ekonomi Perubahan Iklim: Dari Kegagalan Ekonomi Pasar hingga Ekonomi Rendah Karbon, makalah pada Seminar Publik Pertumbuhan Ekonomi Rendah Emisi: Mau Kemana?; 2011. 28 July 2011.

[82] Aldy, Joseph E. dan Robert N. Stavins. Economic Incentives in a New Climate Agreement, Issue Paper The Harvard Project on International Climate Agreements for The Climate Dialogue, Copenhagen, Denmark; 2008.

[83] Badan Kebijakan Fiskal, Kementerian Keuangan RI. Isu-Isu Perubahan Iklim E Kebijakan Fiskal: Inisiatif 2008, Jakarta, BKF;2008.

[84]__. Isu-Isu Perubahan Iklim \& Kebijakan Fiskal: Inisiatif 2009, Jakarta, BKF; 2009.

[85]__. Kerangka Kerja Kebijakan Fiskal Dalam Negeri untuk Pendanaan Perubahan Iklim di Indonesia: Rangkuman Diskusi Kelompok Terfokus Agustus sampai November 2008, Jakarta; 2008.

[86]Biofuel-At What Cost? Government Support for Ethanol and Biodiesel in China, the Global Subsidies Initiative (GSI) of the International Institute for Sustainable Development. Report of GSI from Energy Research Institute of the National Development and Reform Commission.

[87]Berita Resmi Statistik BPS. Pertumbuhan Ekonomi Indonesia. Jakarta; 2012. No.13/ThXV. 6 Februari.

[88]Bluffstone, Rendall A.Environmental Taxes in Developing and Transition Economics. Public Finance Management; 2003. Vol.1.Departemen of Economics University of Redlands.

[89]BP Statistical Review of World Energy, June 2012.

[9o]Bureau of the Environmental Tokyo Metropolitan Government. Tokyo Cap and Trade Program, Japan's First Mandatory Emissions Trading Scheme; 2010.

[91] Bromley, Daniel W. Sufficient Reason; Toward a Theory of Economic Institutions; 2001,Seminar.

http://www.stockholmresilience.org/21/seminar-andevents/stockholm-seminars/previous-seminars/2001/ss-2001/1220-2007-prof.-bromley-on-a-theory-of-economicinstitutions.html.

[92]CEDS UNPAD Strategic Asia Indonesia. Feasibility of The Green Economy: Simulation Results; 2009.

[93]CCICED Annual General Meeting. China's Low Carbon Industrialization Strategy; 2011.

[94]From Sustainable Development to Green Economy. The 2nd International Workshop, Jakarta, UKP-PPP; 2012.

[95]Dessureault, Darlene dan Robin Gray. USDA Foreign Agricultural United States of America, Global Agricultural Information Network. Canada Biofuel Annual 2011.GAIN Report Number $\mathrm{C}_{11036}$

[96]DNPI dan World Bank. Opsi-opsi Pembangunan Rendah Karbon untuk Indonesia, Peluang dan Kebijakan Pengurangan Emisi Sektor Manufaktur. Jakarta; 2009.

[97]Energy and Natural Resources. Taxes and Incentives for Renewable Energy. Departemen of Tax, June 2011, www.kmpg.com

[98]European Union Country Report. Trend in Global Energy Efficiency 2011. the latest update January 2011
[99]European Environment Agency. Environmental tax reform: increasing individual incomes and boosting innovation; 2012.< http:// www.eea.europa.eu/ highlights/environmental-taxreform-increasing-individual>.

[10o] Flach, Bob, dan Stephen Huete. USDA Foreign Agricultural Service United States of America. Netherlands-Germany EU27 Biofuel Annual Report 2009, Global Agricultural Information Network GAIN Repor; 2009, Number: NL9014

[101] Hadad, Ismid. Pendahaan Untuk Menanggulagi Perubahan Iklim: Mitigasi, Adaptasi, CDM, REDD+. Presentasi Seminar Perubahan Iklim, Jakarta; 2010.

[102] Hardee, Karen, at.al. The Policy Circle". USAID, Policy Working Paper Series; 2004, No.11.

[103] Hinman, Jeffry S. The Green Economic Recovery: Wind Energy Tax Policy After Financial Crisis and American Recovery and Reinvestment Tax Act of 2009. University of Oregon School of Law 2009, In: Energy Info, Energy Review 2007 Departement of Energy United States of America; 2007.

[104] AICPA. Guiding Principles of Good Tax Policy: A Framworkl o Evaluating Tax Proposals. New York. American Institute of Certificate Public Administration, Inc.; 2001.

[105] Imansyah, Handry M, at.al. Identification of Key Sector in $\mathrm{CO}_{2}$ Emission in Production Perspective of Indonesia: an InputOutput Analyis. Paper presented for the 23rd PRSCO adn the 4th IRSA Institute, Bandung; 2013, 2-4 July 2013.

[106] Imori, Denise dan Joaquim Jose Martins Guilhoto. Brazillian productive structure and $\mathrm{CO}_{2}$ emissions, Paper, Brazil; 2010).

[107] Indian Wind Energy Outlook 2009, Global Wind Energy Council ( GWEC)

[108] Indonesia Energy Outlook 2010, Pusat Data dan Informasi ESDM Kementrian ESDM.

[109] IPCC. Climate Change 2007: Mitigation of Climate Change; 2007. http://www.ipcc.ch/publications_and_data.

[110] John Robinson.at.al. Climate Change and Sustainable Development: Realizing the Opportunity. Ambio; 2006 Vol.35, No.1, p:3 http://www.jstor.org/stable/4315675.

[111] Koplow, Dough. A Boon to Bad Biofules, Federal Tax Credit and Mandates Underwrite Environtmental Damage at Taxpayer Expenses, Earth Track, Friends of the Earth.

[112] KPMG. The KPMG Green Tax Index 2013, An Exploration of green tax incentives and penalties; 2013.< kmpg.com/greentax>.

[113]Locatelli at.al. Menghadapi Masa Depan Yang Tidak Pasti. Perspektif Kehutanan. Bogor: CIFOR; 2009, No.5.

[114] Machado, Giovani Victoria. Energy Use, $\mathrm{CO}_{2}$ Emissions and Foreign Trade: an IO Approach Applied to the Brazilian Case. Paper at 13th International Conference on Input-Output Techniques, 21-25 August 200o, Macerata, Italy; 2000.

[115]Masterplan Percepatan dan Perluasan Pembangunan Ekonomi Indonesia 2011-2025, Jakarta: Kementrian Koordinator Bidang Perekonomian; 2011

[116] Meisen, Peter, Overview of Renewable Energy Potential of India 2006, Global Energy Network Insititute (GENI).

[117]Metcalf, Gilbert E dan David Weisbach. Lingking Policies When Tastes Differ: Global Climate Policy in a Heterogeneous World. Discussion Paper 10-38, The Harvard Project on International Climete Agreements, USA, Harvard Kennedy School; 2010.

[118] Ministry of Finance Green Paper Economic and Fiscal Policy Strategies for Climate Change Mitigation in Indonesia, Jakarta;2009.

[119] National Report On Biodiesel in Bulgaria, Biodiesel Chains EIE-05-114, ESD Bulgaria.

[120] Preechajarn, Sakchai dan Ponnarong Prasertsri, Thailand Biofuel Annual 2010, USDA Foreign Agricultural Service United 
States of Americal, Global Agricultural Information Network GAIN Report Number THoog8

[121] Prince, Lynne Christina Galitsky, Jonathan Sinton. Tax and Fiscal Policy for Promotion of Industrial Energy Efficiency: A Survey of Internasional. USA: Berkeley; 2005.CA 94720.

[122] Puspiptek BPPT; 2010. http://puspiptek.ristek.go.id/media.php?module=home.

[123] Puri, Jo (Jyotsna) dan Semhar Mehbratu. Green EconomySome Frequently Asked Questions In the Context of Developing Countries. Mountain Forum Bulletin; 2011.

[124] Renewable Energy Policy Review the Netherlands. Duurzame Energie In Netherlands 2007, Bureau of Statistic.

[125] Riphat, Singgih. Peran Strategis Kementerian Keuangan Dalam Mitigasi dan Adaptasi Perubahan Iklim. Climate Change Seminar Presentation, Jakarta; 2010.

[126] Roberts, Melanie. Somerset Local Economic Assessment. Low Carbon Economy Briefing Paper; 2010.

[127] Rosdiana, Haula. Spektrum Teori Perpajakan Untuk Pembangunan Sistem Perpajakan Indonesia Menuju Persaingan Global. Pidato pada Upacara Pengukuhan Guru Besar Tetap Bidang Ilmu kebijakan Pajak FISIP UI. Jakarta ;2013.

[128] Salim, Emil. Green Fiscal Policy to Combat Climate Change. Universitas Indonesia; 2002.

[129] Shiro Takeda. An Economic Analysis of Environmental Regulations. Japan: Kanto Gakuen University.

[130] Ter-Minassian, Teresa. Adapting Fiscal Policy to Deal with Climate Change. Presentasi Seminar, Bali; 2008.

[131]Tanzi, Vito. Measuring Efficiency in Public Expenditure. World Bank; 2004.

[132] United Nation. Committee of Experts on International Cooperation in Tax Matters Seventh session. Geneva; 2011.

[133]_ Tax Incentives and Foreign Direct Investment, A Global Survey.New York adn Geneva, UNCTAD/ITE/IPC/Misc.3; 2000.

[134] United Nations Division for Sustainable Development (UNDSD). The CSD Work Programme on Indicators of Sustainable Development. Working Paper No. 27.< http://www.un.org/esa/sustdev/isd.htm>.

[135] Virtual Economy Glossary, '(Neo-)Classical Theory Policies.http://www.bized.ac.uk/virtual/economy/library/theor y/classical 4. htm.

[136] United Nations Economic Programs. Green Economy Indicators". Briefing Paper; 2012.

[137] World Bank; 2013. <http://www.worldbank.org/en/country/indonesia/overview>.

[138] Zolt, Eric M. Tax Incentives in a BEP World. UN Workshop. May; 2014.

[139] _ Bantuan Australia Memperkuat kebijakan Fiskal Indonesia” <http://id.voi.co.id/fitur/voi-bunga-rampai/3977bantuan-australia-memperkuat-kebijakan-fiskal-

indonesia.html>. accessedon 21 Nov 2010.

[140]__ . "Pajak dan Subsidi untuk Perubahan Iklim: Sebuah tulisan untuk menyambut pertemuan tingkat tinggi Menteri Keuangan untuk Perubahan Iklim”, Warsawa, Polandia, 8-9 Desember 2008. <http://www.pksi.depkeu.go.id/pub.asp?id=14>.accessedon 23 Nop 2010. 